AJIE - Asian Journal of Innovation and Entrepreneurship

(e-ISSN: 2477- 0574; p-ISSN: 2477-3824)

Vol. 02, No. 02, May 2017

\title{
GROWING A TECHNOPRENEURSHIP-BASED NEW ENTREPRENEUR IN BUSINESS INCUBATOR
}

\author{
Kunto Adi ${ }^{1}$, Erlyna Wida Riptanti ${ }^{2}$, Heru Irianto ${ }^{3}$ \\ ${ }^{1}$ Cooperative and SMEs Facilitation Study Center \\ And Teaching Staff of Agribusiness Study Program of Agricultural Faculty of UNS Surakarta \\ email: kuntouns@gmail.com
}

\begin{abstract}
Activity-based growth of new entrepreneurs at the Business Incubator's Technopreneurship general aim is to increase the capacity building of Business Incubator Unit PSP-MSME and SME tenants so as to improve students technoprenership-based entrepreneurship. Special Interest devotion second year: 1) Develop a productive unit that has been established in the first year, 2) Conducting the process of recruitment and selection of candidates SME tenants from students or alumni of UNS, 3) Improve the skills and knowledge of the field of productive business tenant.

The results of activities in the second year are selected 10 tenants who pass the program to continue the business of fruit chips "Amaji Food". The tenant learned from the process of procurement of raw materials, production processes, packaging to marketing. Various exhibitions are also attended by the tenant in introducing the product "Amaji Food" to the public. The tenant also diversified its new products started to produce chips, carrots, radishes, beans and pumpkin. However, the new product is still in early stages of introduction to the market to evaluate the response of the market.
\end{abstract}

Keyword: Incubator, entrepreneurs, technoprenership

\begin{abstract}
ABSTRAK
Kegiatan penumbuhan wirausaha baru berbasis technopreneurship di Inkubator Bisnis ini tujuan umumnya adalah meningkatkan capacity building Unit Inkubator Bisnis PSP-KUMKM dan UKM tenant sehingga dapat meningkatkan mahasiswa berwirausaha berbasis technoprenership. Tujuan khusus pengabdian tahun kedua : 1) Mengembangkan unit usaha produktif yang telah didirikan pada tahun pertama, 2) Melakukan proses rekruitment dan seleksi calon UKM tenant dari mahasiswa atau alumni UNS, 3) Meningkatkan keterampilan dan pengetahuan tenant bidang usaha produktif.

Hasil kegiatan pada tahun kedua ini adalah terseleksi 10 tenant yang lulus program untuk melanjutkan usaha kripik buah "Amaji Food". Para tenant belajar mulai dari proses dari pengadaan bahan baku, proses produksi, pengemasan sampai pemasaran. Berbagai event pameran juga diikuti oleh para tenant dalam mengenalkan produk "Amaji Food" kepada masyarakat. Para tenant juga melakukan diversifikasi produk baru yaitu mulai memproduksi kripik wortel, lobak, buncis dan waluh. Namun, produk baru ini masih dalam taraf pengenalan ke pasar untuk mengetahui respon pasarnya.
\end{abstract}

Keyword : Inkubator, wirausaha, technoprenership 


\section{INTRODUCTION}

Indonesian unemployment rate, according to Central Statistic Bureau in the mid of February 2016 is still fairly high, reaching 7.02 millions people or 5.5 percents, despite the decreased rate compared with that in February 2015, 7.45 millions people $(5.81 \%)$. While total unemployment rate tends to decrease, the educated unemployment rate tends to increase. In 2012 the educated unemployment rate is 8.79 percents (645,866 people) and this figure decreased to 8.36 percents $(619,288$ people) in 2013 but increased to 9.5 percents $(688,660$ people) in 2014 out of the total unemployed constituting the alumni of colleges. Such the condition is the challenge to College not only to undertake their duty as graduate producer but also to contribute to growing and developing their graduates' competency to be the creator of job opportunity rather to be job seeker.

Incubator of PSP-KUMKM (Cooperative and SMEs Facilitation Study Center) of Sebelas Maret University established in 2011 legalized by the Rector's Decree No: 2A/UN27/HK/2013, according to the vision it assumes, serve as the media of undertaking incubation process to micro-, small- and mediumscale enterprises (SMEs) tenant through services (facilitator, providing place and other supporting infrastructures), organizing training, and facilitation for the improvement of accessibility (business information, technology, funding, business capacity reinforcement, institution, and product marketing) (Erlyna, et al, 2012).

The function of incubator, as the part of college constituting the strategic institution, is to develop the capacity of SME performers so that the substantial unemployment rate still encourages the Incubator of PSP-KUMKM to participate and to encourage and to grow entrepreneurs specifically for the finalyear students or its alumni. This technopreneurship-based program of growing new entrepreneurs entering its second year is intended to enable the students and alumni to be ready for having entrepreneurship independently around or after their graduation; in addition, this program is also intended to improve the capacity building of incubator units. The program of growing new entrepreneurs based on technopreneurship is held to deal with the following problems:

1. There should be Capacity building improvement for Business Incubator Unit

The Business Incubator Unit of PSPKUMKM is still young so that its management has not been conducted maximally yet. Financial source to fund the operation should be explored in order to optimize its role and function in providing 7S: Space, Shared, Services, Support, Skill development, Seed capital, and Synergy. One attempt taken in exploring the financial source is to optimize the utilization of existing facility by establishing the technologybased productive business unit.

On the other hand, students and alumni likely underestimate the existence of Business Incubator Unit of PSPKUMKM because there has no real evidence of productive business under the management of Business Incubator Unit. Through establishing productive units under Business Incubator, the 7Sservice function can be improved particularly in improving support and skill development to its tenant. 
2. Students' or alumni's motivation in having technopreneurship-based entrepreneurship should be improved.

The potency of UNS' students and alumni is substantial in utilizing technology to work or to be entrepreneur. However, this potency has not been managed well because of the students and alumni's low motivation in being entrepreneur. Entrepreneur is not the primary choice in finding income source, but because of urgency. Meanwhile, if this potency can be managed well, it will give better result when compared with the due-tourgency entrepreneur.

Only few students receiving competitive grant from PMW and PKM whose business continues after the program completion. The failure in business is one factor leading them not to continue their initiated business.

3. Students and alumni facilitation in being entrepreneur is relatively low The facilitation for the students receiving competitive grant from PMW and PKM had not functioned optimally yet so that the business failure occurs. Business Incubator unit, among others, serves to conduct facilitation for the tenants and SMEs needing. However, the students or alumni of UNS still utilize this function rarely in managing their business.

From the problem statements above, the general objectives of current activity is to improve capacity building in the Business Incubator Unit of PSP-KUMKM and tenant SME thereby improving the students' entrepreneurship based on technopreneurship. Meanwhile, the second-year objective is specified as the result of an evaluation on the first-year program result while still referring to general objectives:

1) Developing productive business unit established in the first year

2) Conducting recruitment process and selecting the prospect tenants consisting of students or alumni of UNS

3) Improving the tenants' skill and knowledge on productive business area.

\section{LITERATURE REVIEW}

One attempt the government takes to grow and to develop small employers is through business incubator and technology program. It is because incubator is an institution that develops the prospect employers to be independent employers through a series integrated building involving providing workplace/office, office infrastructure, management guiding and consultation, research and development grant, training, capital grant, and creating business network at both local and international levels (Panggabean, R., 2006).

During 1992-2010 in Indonesia 32 incubators have developed. Most incubators are in the colleges. Nevertheless, it has not shown the delightful development. The poor development of incubator in Indonesia has been studied due to some factors. In addition, because of its relatively young age and learning (inexperienced) stage, there are some determinants of incubator's poor development in Indonesia: (a) limited availability of operational facility leading to the low ability of absorbing tenants, (b) inadequate seed capital support so that incubator has not been dealt with professionally and many tenants cannot get 
seed capital despite their business's feasibility to be funded, and (c) government's commitment and support is relatively low and inconsistent in developing incubator (Iskandar, 2011).

\section{Although entrepreneur}

development model through incubator model develops inadequately, actually incubator mode is considered as having distinctive strength, because through incubator model, it is expected that new more professional entrepreneurs will grow that can produce more competitive product and services. It is possible because in incubator program, the prospect entrepreneurs are educated to master any business aspect and equipped with the working media and capital. In addition, College incubator can serve as technology transfer as well to support the acceleration of business realm (Setiawan, 2005).

\section{SERVICE METHOD}

\section{Solution and method offered}

The improvement of capacity building of both incubator and tenant was conducted gradually starting from funding source, management improvement, optimization of existing resource use to broader network establishment. It is conducted by referring to the target of PSP-KUMKMS business incubator in 2022 constituting the unit with independent management. Meanwhile, the target of technology-based new entrepreneurship growing in the third year should have entered the incubation program. Considering the problems above, the solution and approach method offered is as follows:

\section{Second Year}

a. Productive business unit development
Business unit established in the first year is developed for sale volume, profit, packaging, and product diversification. It was conducted as the successful example of technologybased entrepreneur implemented in the campus.

b. Recruitment and selection of UNS students or alumni to be the tenants.

Recruitment and selection of students and alumni is conducted to find the prospect entrepreneurs with strong interest, motivation and will in being technology-based entrepreneur. The successful Business Incubator is affected by recruitment and selection process. This process becomes very important, so that the error selection can be minimized. Recently, there is a phenomenon that only students or alumni receiving entrepreneurship grant can benefit from the program. In this program 10 tenants would be selected.

c. Tenant apprenticeship process in Business Incubator productive business unit.

Having passing successfully through the tenant selection, the next step is apprenticeship process for about 2 months in farming crop processing production business unit. Tenants do a wide range of works from providing raw (basic) material, selecting, producing, packaging to marketing. The tenants are expected to do their work independently having passed successfully the program.

d. Business plan development and facilitation

Business plan should be planned maturely, one of which is by developing business plan. Tenant will be directed and guided in developing 
business plan on the business area to be run.

e. Vacuum frying improvement

Vacuum frying used continuously becomes worn out in which some elements of vacuum are damaged and should be replaced. The repairing process should be done immediately in order to continue the production process and to be used as the apprenticeship site.

\section{The Work Procedure to Support the Method Offered}

The implementation of offered method is devised to be conducted for 3 years. Overall, the methods used in the implementation of this second-year activity are recruitment, practice, technical guiding/training and productive business facilitation. The detail of work procedure in supporting the method offered is as follows:

1. The development of first-year productive business unit

a. The procedure includes the team conducting an evaluation on the result in production business unit concerning the development of production, sale volume, and profit, and the effectiveness of strategies taken. The team specified the target of production achievement, sale volume, and profit.

b. The team identifies and formulates the strategies that can be implemented in achieving the targeted production, sale volume and profit.

c. Team implements the formulated strategies in achieving the target.

2. Recruitment and selection of UNS students and alumni to be the tenants a. The procedure is done by socializing the recruitment of prospect tenant SME coming from the students or alumni. The basic requirements to be prospect tenants are students or alumni, having interest in, motivation and intention to be entrepreneur. In addition, they should have idea of technology-based or start-up business.

b. Team conducts selection including selection, administration, business plan presentation and interview.

c. Team decides and announces that 10 students/alumni passing successfully the selection becomes the Business Incubator's tenants.

3. Tenant apprenticeship process in Business Incubator's productive business unit.

a. The procedure is done through socializing the apprenticeship to the tenants passing successfully the selection and preparing the place and job description in Business Incubator's production business unit.

b. Team facilitates the tenants' business apprenticeship for 2 months in Business Incubator's productive business.

c. Team monitors and evaluates the tenants' apprenticeship.

4. Business plan development

a. The procedure is done through explaining the development of technology-based business plan.

b. Team facilitates the tenants in organizing business plan in the technology-based area. 


\section{Partner Participation}

This service activity needs partner support from the Organizer of Cooperative and SME Facilitation Study Center to achieve the successful program. Partner participation is demonstrated with the commitment of in kind fund sharing of IDR $10,000,000$ per year. In addition, the partner is committed to improve the performance of Business Incubator collectively.

\section{Result and Discussion}

The Service Team coordinates the activities that has and will be achieved in the first year and the activity planned in the second team. The team designs the activities to be implemented in the second year. The stages of activity are explained as follows:

Table 2. The schedule of IbPTK Activity in 2016

\begin{tabular}{|c|c|c|}
\hline No & Activities & Period \\
\hline 1 & $\begin{array}{l}\text { Production tool (vacuum frying) repairing } \\
\text { a. Repairing/replacing filter } \\
\text { b. Ordering reservoir tub }\end{array}$ & $\begin{array}{l}\text { The first week of August } \\
2016\end{array}$ \\
\hline 2 & Installing water installation & 21-25 July 2016 \\
\hline 3 & $\begin{array}{l}\text { Tenant recruitment (10 tenants) } \\
\text { a. Publication } \\
\text { b. Selection } \\
\text { c. Announcement }\end{array}$ & $\begin{array}{l}\text { 19-25 July } 2016 \\
26 \text { July } 2016 \\
28 \text { July } 2016\end{array}$ \\
\hline 4 & Socializing the apprenticeship & 3 August 2016 \\
\hline 5 & $\begin{array}{l}\text { The apprenticeship of } 10 \text { tenants (production } \\
\text { process, packaging and marketing) } \\
\text { (1-week tool trial has been conducted, } \\
\text { Starting from production process, preparing product } \\
\text { for monitoring and evaluation, on August 2016) }\end{array}$ & $\begin{array}{l}\text { Starting from the } 4^{\text {th }} \text { week of } \\
\text { August } 2016 \text { for } 1 \text { month. }\end{array}$ \\
\hline 6 & $\begin{array}{l}\text { PIRT administration } \\
\text { (preparing PIRT administration document, } \\
\text { preparing place and tool) }\end{array}$ & $\begin{array}{l}\text { The second week of } \\
\text { November } 2016\end{array}$ \\
\hline 7 & $\begin{array}{l}\text { Comparative study to KPI (Kepurun Pawana) } \\
\text { The part of apprenticeship activity }\end{array}$ & $\begin{array}{l}8 \text { August - } 27 \text { September } \\
2016\end{array}$ \\
\hline 8 & $\begin{array}{l}\text { Business Plan Development (10 tenants) } \\
\text { a. Training } \\
\text { b. Facilitation }\end{array}$ & $\begin{array}{l}8 \text { August } 2016 \text {, at } 01.00 \\
\text { p.m. } \\
9-25 \text { August } 2016\end{array}$ \\
\hline 9 & $\begin{array}{l}\text { Continuing the fruit chip business by selected } \\
\text { tenants }\end{array}$ & $\begin{array}{l}\text { Starting from September } \\
2016\end{array}$ \\
\hline 10 & Facilitating the tenants in fruit chip business & $\begin{array}{l}\text { Starting from September } \\
2016\end{array}$ \\
\hline
\end{tabular}

The activities conducted in this second year include:
1. The recruitment and selection of UNS students and alumni to be the tenants 
The service team coordinated in recruiting and selecting the tenants. The requirement specified in the recruitment process included: the finalyear students/fresh graduates of both graduate and undergraduate (D3/S1) programs in all study programs/faculties. The administration registration process was opened on July 19-25, 2016 and the registered participants would be interviewed on July 2016.

There were 20 applicants including the students/fresh graduate of undergraduate/graduate study program of Agricultural Faculty of UNS. The list of prospect tenants registering in this program is presented below:

Table 2. List of Prospect Tenant Participants.

\begin{tabular}{|c|c|c|}
\hline No & Participants Name & Origin \\
\hline 1. & Erni NS & D3 Agribusiness \\
\hline 2. & Evi Tri Rahayu & D3 THP \\
\hline 3. & Agustina D & D3 Agribusiness \\
\hline 4. & Lusia Suci C & D3 Agribusiness \\
\hline 5. & Dedy Purwoko & D3 Agribusiness \\
\hline 6. & Yonex Jalu L & D3 Agribusiness \\
\hline 7. & Tabliqiyah Kurniawat & D3 Agribusiness \\
\hline 8. & Endang Palupi & S1 ITP \\
\hline 9. & Abinawa Heri N & S1 Livestock \\
\hline 10. & Asa Datu N & S1 Agribusiness \\
\hline 11. & Lucky Yoga & S1 Agribusiness \\
\hline 12. & Alfian Eko N & S1 Agribusiness \\
\hline 13. & Feti Munika & S1 Agribusiness \\
\hline 14. & Syafiq & S1 Agribusiness \\
\hline 15. & Linda Cahya N & D3 THP \\
\hline 16. & M. Luthfi I & D3 THP \\
\hline 17. & Miftachul Ikhsan & D3 THP \\
\hline 18. & Sonia A & D3 THP \\
\hline 19. & Junjung Agung K & D3 THP \\
\hline 20. & Sidiq Dwi Arianto & S1 THP \\
\hline
\end{tabular}

The interview selection with the 20 participants would be held on
July 26, 2016. The interview selection focused on the high motivation to be 
entrepreneur. Here is the process of

program:

selecting the tenant prospects in this
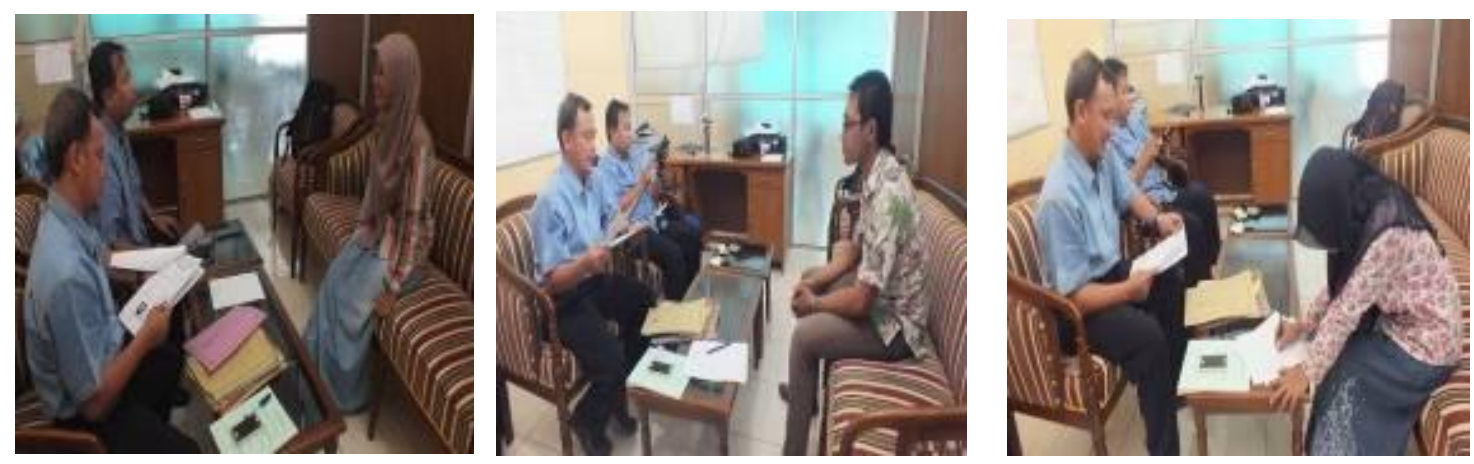

Figure 1. Prospect Tenant Selection Process

Some participants only wanted to register leisurely so that they got bad score. The result of interview selection is obtained from 10 tenants passing successfully the apprenticeship program, as presented below:

Table 3. The list of selected tenants

\begin{tabular}{|c|l|c|c|}
\hline No & \multicolumn{1}{|c|}{ Name } & Study Program & Phone Number \\
\hline 1 & Evi Tri Rahayu & D3 THP (alumni) & 089618039551 \\
\hline 2 & Agustina D & D3 Agribusiness (alumni) & 085728575806 \\
\hline 3 & Lusia Suci C & D3 Agribusiness (alumni) & 081578940271 \\
\hline 4 & Yonex Jalu & D3 Agribusiness (alumni) & 085742313209 \\
\hline 5 & Tabliqiyah Kurniawati & D3 Agribusiness (alumni) & 087734824723 \\
\hline 6 & Endah Palupi & S1 ITP & 085725506694 \\
\hline 7 & Abinawa Huri N & S1 Livestock & 085655255523 \\
\hline 8 & Asa Datu Niwanda & S1 Agribusiness & 085725695571 \\
\hline 9 & Lucky Yoga & S1 Agribusiness (Alumni) & 085728814828 \\
\hline 10 & Alfian Eko Nugroho & S1 Agribusiness & 08122519031 \\
\hline
\end{tabular}

The participants passing successfully the tenant selection in this IbPTK program were then discussed in coordination meeting on August 3, 2016 in PSP-KUMKM office. In the coordination, the Service Team and the program participants approved the activity schedule to be conducted. The coordination meeting can be seen below: 

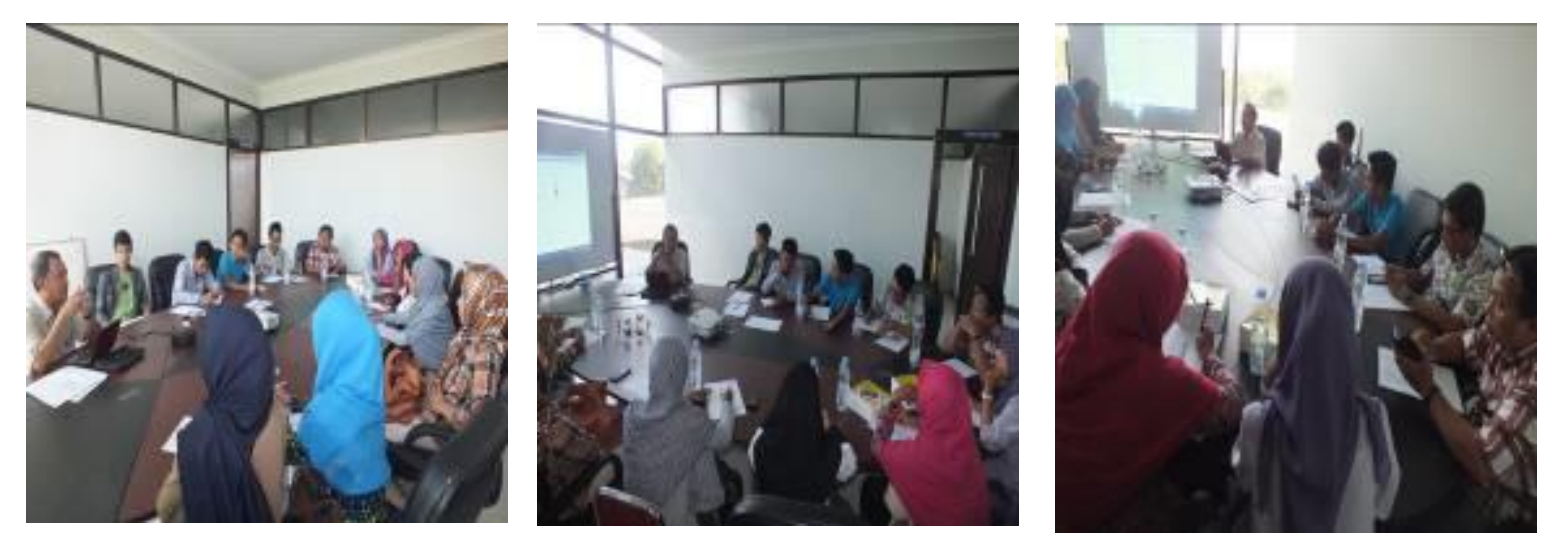

Figure 2. Coordination Meeting between

Service Team and Program Participants.

2. Business Plan Development and facilitation

Business plan is the business document becoming the reference for the entrepreneurs and the important document that can be offered to others to fund its operation. The service team has gotten information that there are some offering of business plan proposal application from donor institutions. For that reason, the business plan development training would be held on August 8, 2016 in PSP-KUMKM office.

The business plan proposal submitted to the third party includes:

a. Alfian, product: garment (2 years) b. Yonex, product: herbal instant beverage (3 months)

c. Endah Palupi, product: clothing (6 months)

d. Asa Datu, product: gift (painting mug, snack bucket) (2 months)

e. Agustina, product: red ginger seedling (1 month)

f. Tabliqiyah, fruit chip

g. Evi Tri Rahayu, fruit chip

h. Lusia, fruit chip

i. Lucky Yoga, mushroom chip

j. Abinawa, Tahu Tuna

Here is the documentation during business plan development training.
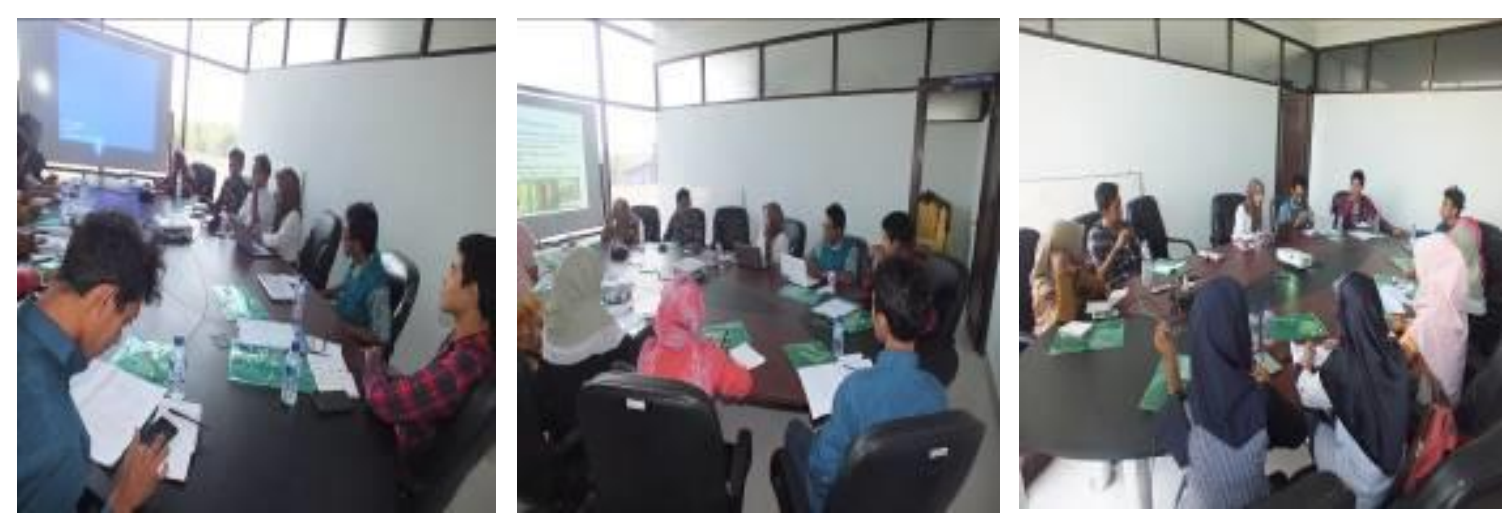

Figure 3. Business plan development training 
The facilitation of business plan proposal writing started from August 9, 2016, because there is an offering from donor institution the
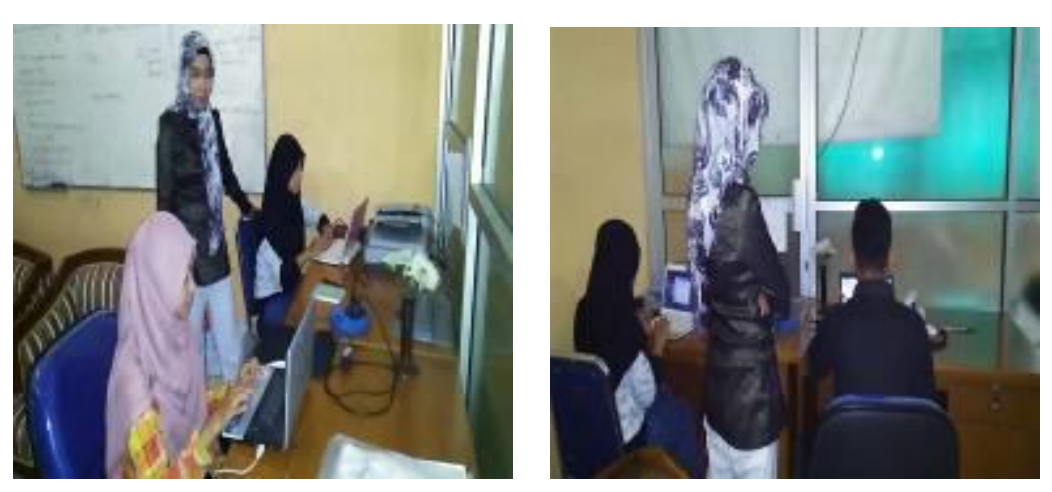

Figure 4. The facilitation in business plan proposal writing

Out of 10 tenants successfully sending the business plan proposal, no one passed successfully the selection to get the grant from donor institution. It was because of limited time to develop business plan so that the data necessary to support the proposal was incomplete. Nevertheless, this business plan proposal writing can be the practice in writing further proposal for fruit chip business managed by the tenants. So, when someday there is an offering from donor institution, the tenants will be ready to submit it.

3. Installing the water installation

The absolute requirement in proposing home industry food (PI-RT) business is the presence of water installation in production place. This IbPTK program location has moved from Mesen kampus to pusbangnis building of Purwosari this year, in which there has been no water installation so that it should be installed first in the production location. This installation has been done completely so that it will not deadline of which was on August 25, 2016. Here is the facilitation process in writing the business plan proposal: 
needs reservation and high cost. Here replacing the spare part of vacuum is the process of repairing and frying:
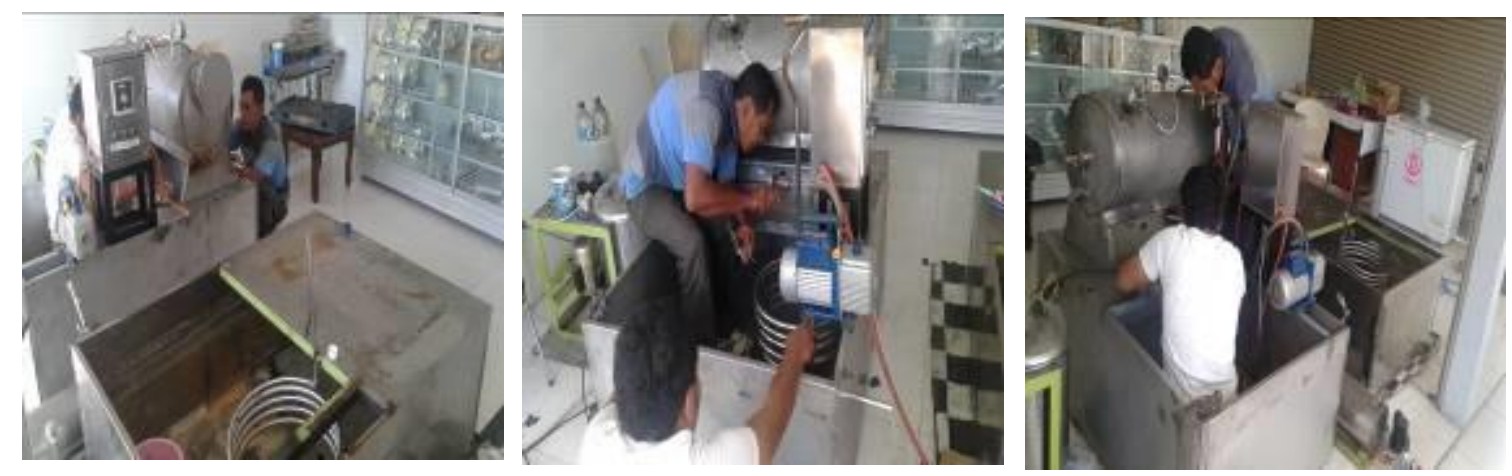

Figure 5. Spare part replacement and vacuum frying repairing

The result of spare part of vacuum frying repairing and replacement is that the tool can be used again according to its functions. Weather temperature and pressure up to -70 can be achieved to produce the crunchy chip fruit. In its usage process, its filter should be cleaned because its capacity is limited.

5. The apprenticeship of tenants in Fruit Chip Business

The tenants passing
successfully the selection of this
IbPTK program participation then
undertook apprenticeship in the fruit
chip processing established by PSP-
KUMKM's Business Incubator Unit in
2015. This apprenticeship process was
conducted after vacuum frying
machine has been repaired completely
for one full month. The Service Team
held training from sorting the fruit raw
material to be used for fruit chip,

cleaning the fruit, slicing, frying, spinning, packaging to marketing.

The apprenticeship in this fruit chip business is one way of approaching the program participants/tenants passing successfully the selection in business realm in which the tenants would continue and develop this business later. Many tenants learn to master the production technology, packaging technology, promotion technology and business management. This apprenticeship process will improve knowledge, skill and insight of tenants in the technopreneurship-based business.

From the result of observation on the apprenticeship process, it can be found that out of 10 tenants attending the program, only 6 tenants actually are committed highly to operate the business. The apprenticeship process can be seen in the figure below: 

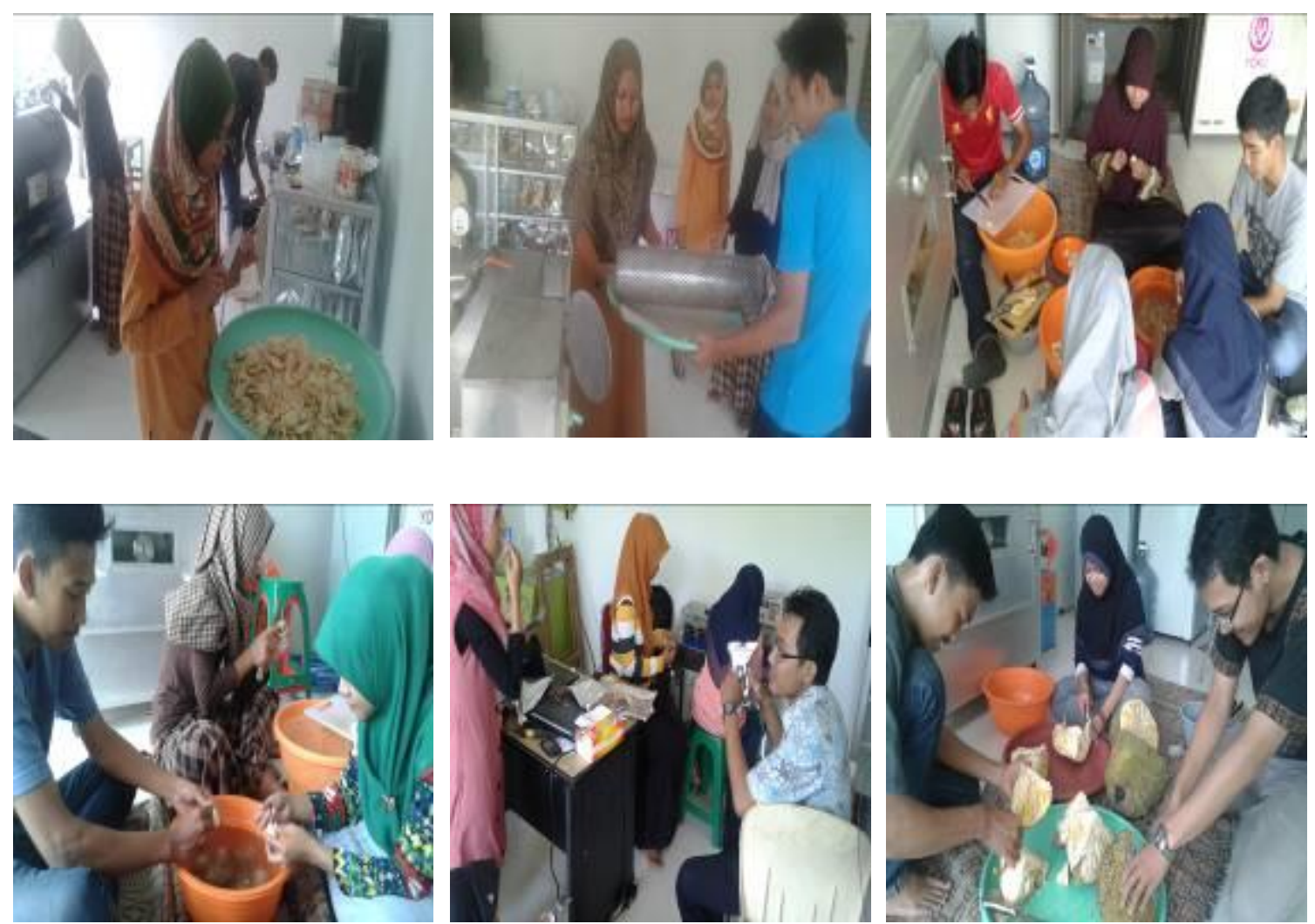

Figure 6. The tenant apprenticeship process in the second-year IbPTK program

There are four tenants with less commitment to apprenticeship process because they should have attended the course and they no longer rented the boarding house so that the transportation cost to commute to is relatively high and takes a long time. In addition, they concentrated on the selection to get a job. Those tenants still want job more than having their own business with uncertain income. It is the dilemma the college's graduates face: building business or working for the company giving income certainty. The implantation of entrepreneurship in Sebelas Maret University has been conducted since the students were admitted through Achievement Motivation Training (AMT) program and entrepreneurship in the curriculum prevailing for all faculties. However, it has not motivated widely the students after passing successfully their education.

6. Tenants' Comparative study on Fruit Chip Business Performer in Turi Sub District of Sleman

Knowledge, skill and insight enrichment is conducted by the tenants by conducting comparative study on the performer of fruit chip processing business in Turi sub district of Sleman. The tenants obtain many things in improving the business viewed from the sorting of fruit raw material, production and marketing process. The result of comparative study within the two first years of fruit chip business established by the business performer in Turi Sub District is a media of learning how to enter the market and 
the challenge they encounter in this area. The comparative study is

facilitated by Service Team as
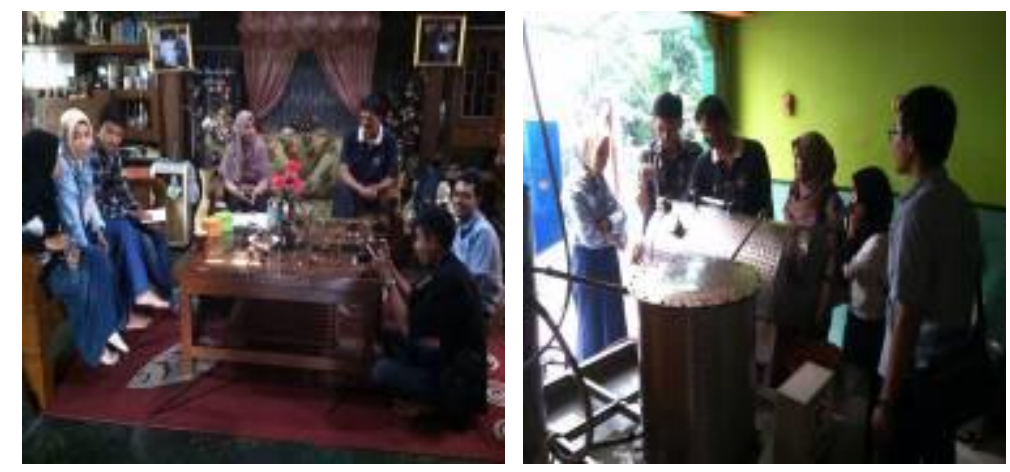

illustrated in the figure below.

Figure 7. A Comparative Study on the fruit chip business performer in Turi Sub District of Sleman man

The quality of fruit chip produced by this business performers is not far different from the one produced by the tenants. The difference lies only in the higher failure level of production process among the tenants due to inappropriate basic material selection. The $80 \%$ fruit maturity is the ideal one to be used for fruit chip. The maturity level higher than $80 \%$ will result in browning process and not-crunchy chip.

The tenants will use the result of comparative study to improve the process of raw material sorting, production and marketing. The willingness to learn from the experience is the positive aspect in operating a business.

7. The administration of PI-RT license

The administration of PI-RT license has been inhibited by the wornout vacuum frying so that the licensing has not been filed again. The management process of fruit chip business conducted by the tenants and the high-quality product lead the application for PI-RT license to be done in Health Office of Surakarta City only. The requirement of application prepared includes: filling in the PI-RT application form completed with the map of production location, product and packaging and recommendation from the authorized one.

Currently, the form and the requirements have been submitted to Health Office of Surakarta City and wait for visitation process. While waiting for visitation process, the tenants produce fruit chip as usual by maintaining the environment cleanliness and sanitation, thereby maintaining its product quality.

8. Business Facilitation to the Tenants in Fruit Chip Business

The fruit chip business in PSPKUMKM's Business Incubator Unit is continued by tenants. This business continued after the tenants undertaking apprenticeship process in this business unit. The Service Team's facilitation to the tenants starts from the location of purchasing cheaper basic material, the strategy to find the supplier of basic 
material, the chip marketer, and business management, to verification.

The fruit chip diversification developed includes pumpkin, carrot, and radish. Mango and pineapple were not selected because it is expensive, leading to the more expensive production cost and affordable price to the consumers. Carrot, pumpkin, stringbean and radish chips were trialed with the market to see the consumer's response to new product including taste, price, packaging and quality wanted. The new product produced by tenants is as follows:
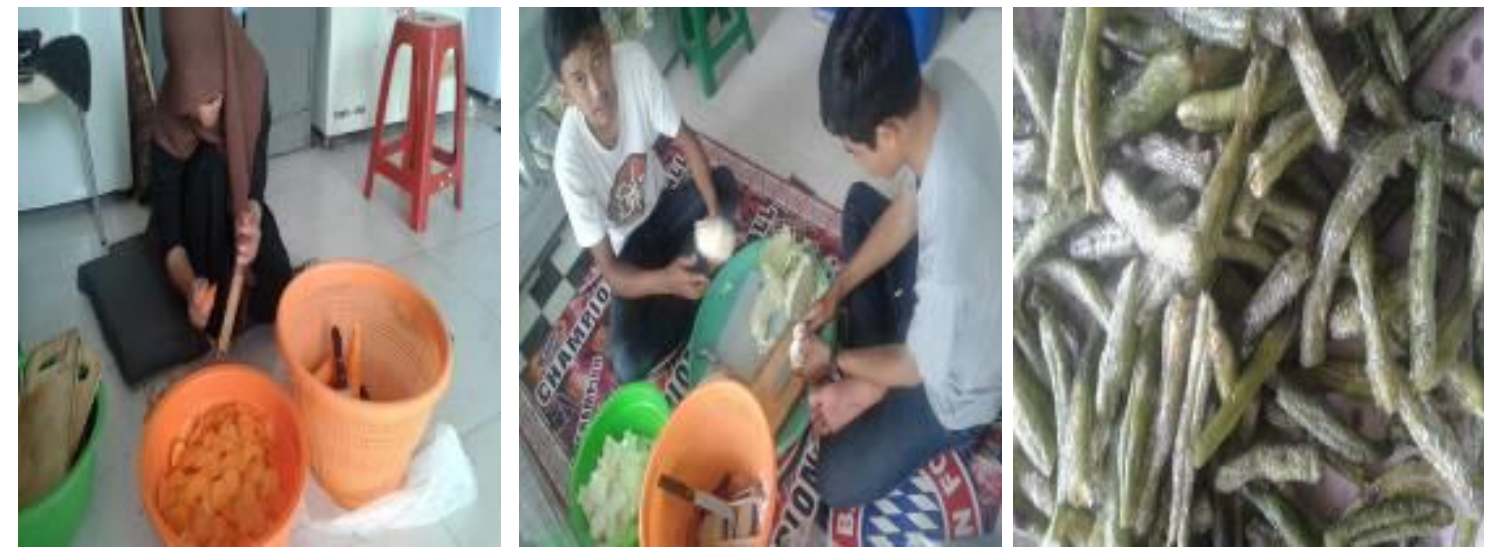

Figure 8 . New product diversification by tenants

The result of tenants' durability of 6 months as long as the production, consisting of zalacca, condition of packaging is still good. jackfruit and apple chip, is dependent on the price of fresh basic material in the market. All fruits produced were The result of fruit chip production produced by tenants can be seen as follows: labeled with "Amaji" brand, with
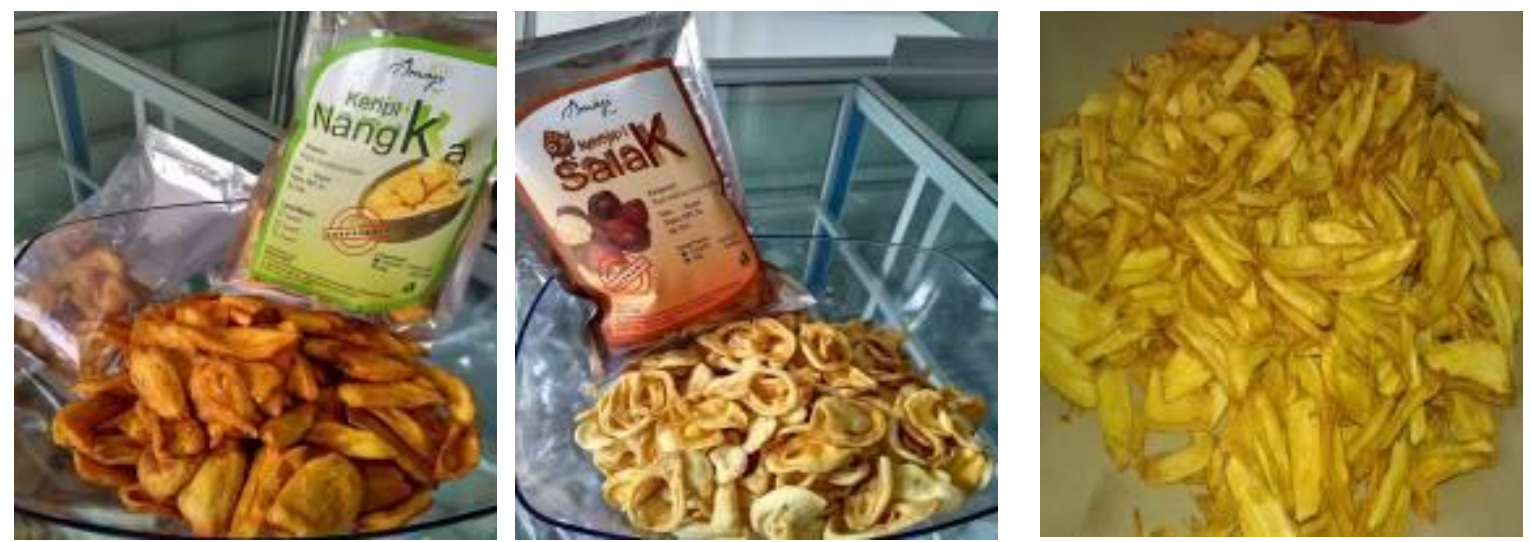

Figure: 9. Tenants' product

The packaging used is aluminum foil entirely with $0.5 \mathrm{~mm}$ thickness. The tenants learn from their experience that when the fruit chip product is packaged in double packaging (plastic and aluminum foil, 
it will soften easily. It is because the air still can enter into the sealed packaged so that the product is less durable. Similarly, when it is packaged with aluminum foil and plastic with thickness of $0.55 \mathrm{~mm}$, the product will not be durable.

The marketing of fruit chip product is conducted by means of making consignment with the gift sellers existing in Solo and Sukoharjo City. The market is also conducted through Sunday market event in both Solo and Karanganyar cities. In addition, to expand the marketing, some SMEs' product exhibitions are also attended, held by the Agricultural Faculty of UNS and Vertenberg Fortress in Solo City. The events during exhibition can be seen below:
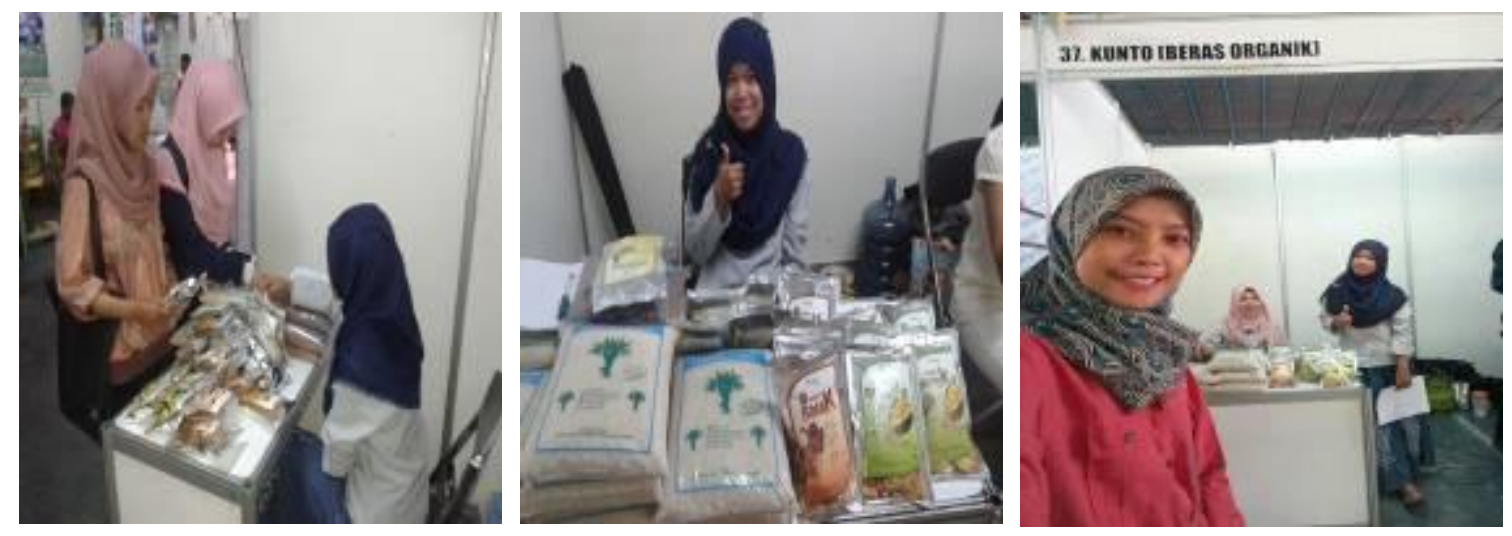

Figure 10. Participation in exhibition events

The response of exhibition visitors is sufficiently good because the quality and price of chips is equal to that of fruit chip produced in Malang/Batu. The price is relatively cheaper than that of Malang/Batu fruit chip existing in gift center of Solo City.

The attempt the tenants took has not been as expected because it still found constraints in the raw material providing process and the broader marketing scope. The tenants are always motivated to maintain their team work compactness. Job description in business management has been divided into 2 divisions: production and marketing. These two divisions are expected to run the fruit chip business more effectively in the business incubator unit of PSPKUMKM-LPPM UNS.

9. The selection of Tenants passing the program successfully

There are 10 tenants passing the selection successfully, but in its development they resigned because of their preoccupation and working outside town so that there are only 6 tenants. The existing tenants are then selected to find out their competency whether or not they pass successfully the program or not based on the managerial ability and technical ability criteria. Considering the result of selection, it can be found that the six tenants have not passed successfully the program so that they still become inwall tenants or Business Incubator. The business performed for the last 2 
years have not contributed selecting the tenants who have passed considerably to increasing the business's profit. The process of and who have not passed successfully
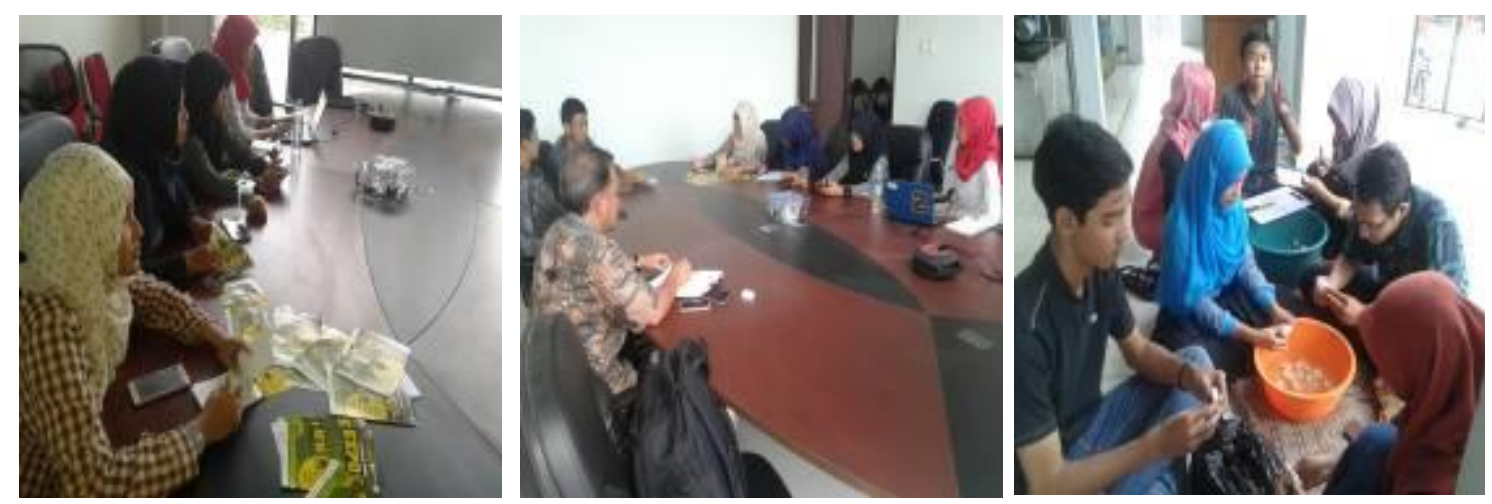

Figure 11. Evaluation on Tenant performance

The tenant not passing successfully the program is still in incubation period. It means that the tenants have not been ready for being relieved from this program. The tenants' soft skill in developing business and sense of business should be sharpened thereby ready for and responsive to the competition in free market. These tenants keep operating the fruit chip business so that this business develops actually as the means of passing examination.

\section{CONCLUSION}

AND

\section{RECOMMENDATION}

\section{Conclusion}

The activity conducted in this second year includes: 1) tenant recruitment process, 2) business plan development training, 3) business plan development facilitation, 4) vacuum frying repairing process, 5) apprenticeship process, 6) comparative study for tenants, 7) productive business facilitation, 8) selecting the tenants passing successfully the program, 9) application for PI-RT licensing. Some modifications have been made to the activities implemented adjusted with the condition of tenant. The result of second-year activity shows that 10 tenants are found passing successfully the program to continue the "Amaji Food" fruit chip business. The tenants learn to start the processes from procuring basic material, production process, packaging to marketing. The tenants also attend many exhibition events to introduce "Amaji Food" to the public. The tenants also diversify the new product starting from producing carrot, radish, stringbean and pumpkin chips. However, this new product is still in introduction level to find out the market's response.

"Amaji Food" business is continued by the second-year tenants passing successfully the IbPTK program located in Pusbangnis Office of Purwosari, Surakarta. This business development has not been far different from that in the first year. It is because individual tenants still search for the superior business and product form in this business. Establishing a solid teamwork still takes time and needs experience in running business. Many 
problems this teamwork faces include basic material selection, production process, packaging, and marketing. The tenants joining this teamwork learn much from the problems occurring. The result of comparative study on the business performer of fruit chip processing in Turi Sleman increase their experience with running the business.

\section{Recommendation}

The facilitation of Service Team to the tenants is conducted at least once in two weeks to see the development of individual tenants' capacity. The Service Team's facilitation starts with sorting the basic material, producing fruit chip, packaging and marketing it. The result is that the tenants still need facilitation continuously to optimize their ability of seeing and utilizing the existing opportunities.

\section{REFERENCES}

Alberti, Fernando; Salvatore Sciascia, dan

Alberto Poli. 2004.

Entrepreneurship Education: Notes on and Ongoing Debate. 14th Annual int. Ent. Conference. University of Napoli Federico II (Italy) 4-7 July 2004

Dandan Irawan. 2014. Pembentukan Inkubator Bisnis.

Erlyna Wida Riptanti, Emi Widiyanti, Heru Irianto, Bekti Wahyu Utami, R. Kunto Adi. 2012. Laporan Akhir Pengembangan Inkubator Bisnis Kerjasama Dengan Perguruan Tinggi Tahun Anggaran 2012. Pusat Studi Pendampingan Koperasi dan UMKM LPPM UNS.
2013. Laporan Akhir

Pengembangan Inkubator Bisnis Kerjasama Dengan Perguruan Tinggi Tahun Anggaran 2013. Pusat Studi Pendampingan Koperasi dan UMKM LPPM UNS.

Ery Supriyadi dan Eka Setiajatnika,. 2009. Inkubator Sebagai Media Transfer Teknologi Dan Pegembangan Kewirausahaan. Jurnal Sains Manajemen dan Akuntansi. Vol 1 No 1 September 2009.

Indra M Yusuf. 2012. Perguruan Tinggi Harus Dukung Peningkatan UKM. http://keuanganlsm.com/perguruan -tinggi-harus-dukung-peningkatan$\underline{\mathrm{ukm} /}$

Iskandar, M. A., 2011. Panduan Pendirian Inkubator Teknologi. Badan Pengkajian dan Penerapan Teknologi.

Kompas, 2016. Kenapa Lulusan Perguruan Tinggi Makin Susah Mendapat Pekerjaan?.

http://edukasi.kompas.com/read/20 16/04/23/17424071/Kenapa.Lulusa n.Perguruan.Tinggi.Makin.Susah. Mendapat.Pekerjaan.

Panggabean, R., 2006. Profil Inkubator Dalam Penciptaan Wirausaha Baru. Kantor Kementian Koperasi dan UKM RI. Deputi Bidang Pengkajian Sumberdaya UKMK.

Rinto Yulhan. 2014. Pengangguran Terdidik. http ://yulhanrinto.blogspot.com/ 2014/03/ pengangguranterdidik.html

Sawitri, A.A., 2016. BPS: Pengangguran Terbuka di Indonesia Capai 7,02 Juta Orang. TEMPO.CO, Jakarta. https://m.tempo.co/read/news/2016 /05/04/173768481/bps- 
pengangguran-terbuka-di-

indonesia-capai-7-02-j.

Setiawan, 2005. Peran Inkubator Bisnis

Dalam Pengembangan

Entreprenuership Melalui Difusi

Inovasi Produk Riset. Direktur

Pusat Inkubator Bisnis Ikopin

(PiBi) Institut Manajemen

Koperasi Indonesia

Tri Siwi Agustima. 2011. Peran Inkubator

Bisnis Perguruan Tinggi Dalam

Meminimalkan Resiko Kegagalan

Bagi Wirausaha Baru Pada Tahap

Awal (START-UP). Majalah

Ekonomi Tahun XXI, No. 1 April 2011

Widaningrum, N. Setyawan dan D.A.

Setyabudi. 2008. Pengaruh Cara

Pembumbuan Dan Suhu

Penggorengan Vakum Terhadap

Sifat Kimia Dan Sensori Keripik

Buncis (Phaseolus Radiatus)

Muda. J.Pascapanen 5(2) 2008:

45-54

Yohnson. 2003. Peranan Universitas

dalam Memotivasi Sarjana

Menjadi Young Entrepreneur.

Jurnal manajemen \&

Kewirausahaan. Vol 5 no 2

September 2003. Surabaya:

Universitas Kristen Petra. 